
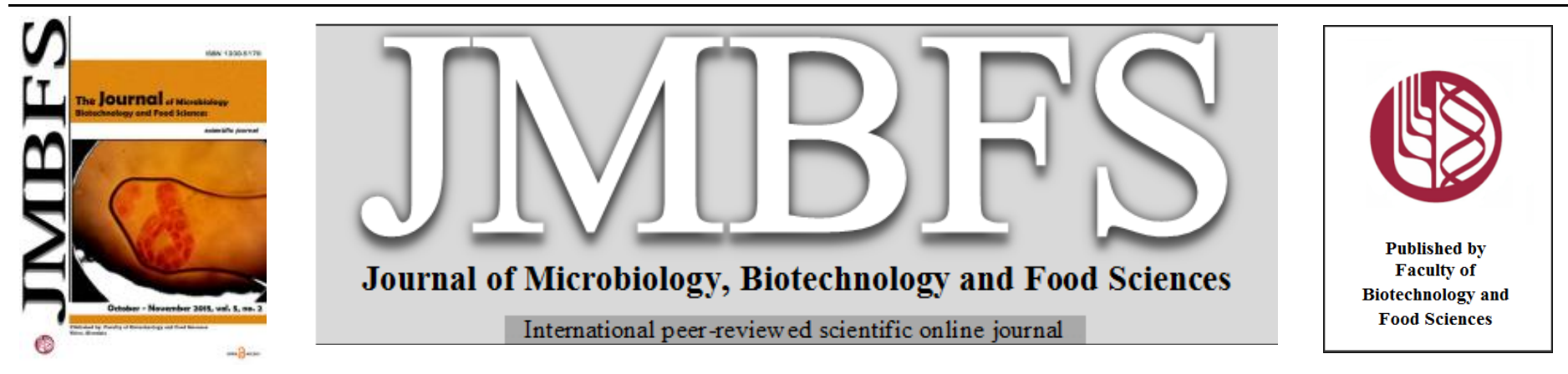

\title{
EXAMINATION OF ENERGY RECOVERY OF BREWERS' SPENT GRAIN I. - CHEMICAL PROCESS
}

\section{Catarina Azevedo Borges ${ }^{1}$, Gábor Géczi $^{* 2}$, Katalin Kovács $^{3}$, Márk Horváth $^{4}$, István Bácskai ${ }^{5}$, Péter Korzenszky ${ }^{6}$}

Address(es):

${ }^{1}$ Federal University of Minas Gerais, Belo Horizonte, Brazil (Scholar of the Science Without Borders at Szent István University in Gödöllö, Hungary).

${ }^{2}$ Szent István University, Faculty of Mechanical Engineering, Institute of Environmental Industrial Systems, Building Automation, Faculty of Facility-, and

Environmental Technology, Gödöllö.

${ }^{3}$ Szent István University, Faculty of Agricultural- and Environmental Sciences, Institute of Environmental Matters, Department of Chemistry, Gödöllő

${ }^{4}$ Szent István University, Regional University Knowledge Centre, Gödöllö.

${ }^{5}$ National Agricultural Research and Innovation Centre (NARIC), Institute of Bioenergetics, Energetically Laboratory, Gödöllö.

${ }^{6}$ Szent István University, Faculty of Mechanical Engineering, Process Engineering Institute, Faculty of Measurement Technology, Gödöllö.

*Corresponding author: geczi.gabor@gek.szie.hu

doi: 10.15414/jmbfs.2015.5.2.116-119

\section{ARTICLE INFO}

Received 9. 4. 2015

Revised 1. 6. 2015

Accepted 17. 6. 2015

Published 1. 10. 2015

Regular article open 2 access

\section{ABSTRACT}

Production rate of technologies applied in the food industry can only be of economical nature if energy consumption is specifically reduced in parallel with increasing the capacities and/or utilization of alternative energy sources gains higher ratio during production. In food manufacturing technologies usually a high proportion of waste/byproduct forms; transportation, recovery and recycling of which involves costs in many cases and simultaneously it also means environmental issues.

Beer brewing industry's most important byproduct is the brewers' spent grains (BSG) which forms during mashing. Utilization of this product is theoretically solved, it is most frequently sold as animal fodder but usage in energy sector also holds promising possibilities. Our study examines the possibilities of energetical recovery of brewers' spent grains by means of chemical processes - such as combustion or pyrolysis - seeking for the economical and environmental advantages.

Keywords: Brewers' spent grains (BSG), burning, pyrolysis, energy recovery

\section{INTRODUCTION}

Spreading and popularity of small scale breweries varies country by country and era by era. Most important factor is the quality of beer of course, however local habits, tax system and economical efficiency of the technology also play a crucial role. In a small- scale technology brewing the beer starts with grinding the barley or malt (Figure 1.). Grinding the malt is in fact a process executed among cylinders which is of vital importance from the perspective of chemicalbiological transformations executed while mashing, qualitative composition and extraction of wort, furthermore yield. Grinding of malt takes place in the small scale practise in mills which have an electric power demand of 1,2-6,8 kW. Nex technology step is the already mentioned mashing during which the grist of malt is mixed with water while slow heating. Aim of the process is that useful substances in the grist of malt like proteins, still soluble starch shall be dissolved at as high ratio as possible and be transformed into sugar. In smaller facilities, home breweries the content of mashing tank is gradually heated to the wished 62 $75^{\circ} \mathrm{C}$ temperature, applying more pauses as and when necessary. Mashing is accomplished with starch transforming into sugar which can be checked by using iodine test. It is self-explanatory that heating involves energy consumption which can be sorted out by electric energy or direct heat energy as well. Mashing is followed by hop boiling which also needs reasonable amount of energy, during which wort is most often boiled at $90^{\circ} \mathrm{C}$ for 90 minutes and simultaneously hop or hop pellet is added in several portions. This extract is pre-cooled in a heat exchanger and thereafter the biological decomposition of sugar takes place in either a room- or cover-cooled fermenting house. In very few cases can the refrigeration be solved without energy consumption. This technology demands for further energy consumption for pumping and circulating the liquids (water, wort, etc.). (Bamforth, 1998; Briggs, 1998; Géczi et al., 2014; Ivanišová et al., 2011; Narzis, 1981)

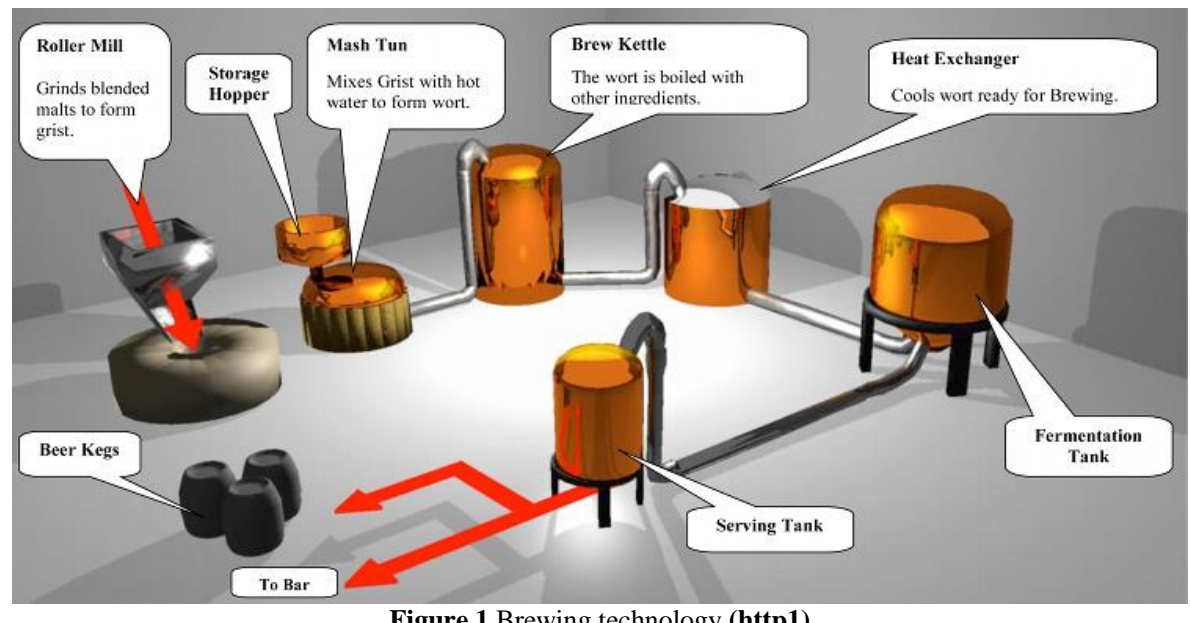

Figure 1 Brewing technology (http1) 
Small scale practice uses electric energy for grinding, circulating the liquids and cooling, but in many cases mashing and hop boiling is also carried out by using electric heating elements. Of course, brewing and boiling can be executed by gas heaters or furnaces using solid state fuel. These instruments however are capable or can be made capable of utilizing alternative energy sources. (Biogas, biomass, waste, etc.)

Referring to examples in Germany, a brewery with $100.000 \mathrm{hl} /$ year capacity even with favorable energy consumption $\sim 100 \mathrm{MJ} / \mathrm{hl}$ specific heat energy-, and $\sim 9$ $\mathrm{kWh} / \mathrm{l}$ specific electric energy consumption can be taken into consideration. Specific energetical factors of small facilities are usually higher than those of larger scale factories (Galli és Zilahy, 2002).

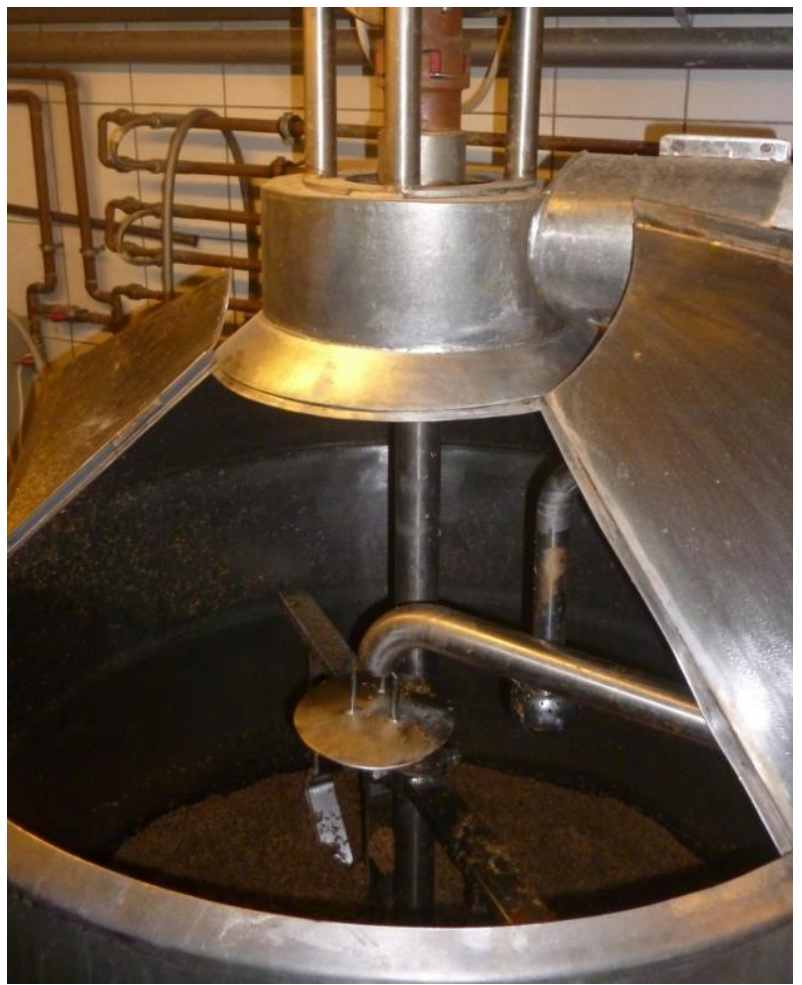

Figure 2 Brewers' spent grain (BSG)

Source: Legenda Brewery, Budapest

Largest scale byproduct of beer brewing is brewers' spent grains which is a residue of mashing (Figure 2) (Mussatto et al., 2006). Leaving the mashing tank, it is still hot and has high humidity content (w>70\%). Humidity content barely reduces in the intermediate storage tanks; therefore it is not appropriate for combustion in this state. Storage in this form is an issue due to fermentation processes and forming odors.

Examples from Hungary show that there is a solution for „removing”, brewers spent grains is most frequently used as animal fodder, but after composting it can also be sold as organic manure. Furthermore researches prove that it is an excellent complementary human nutrient, and might as well be used by the building industry. However, there is no energetic utilization in the mentioned examples although it could be a theoretical possibility for the brewery to partially cover its energy demands (Aliyu and Bala, 2011; White et al., 2008). It is manageable with mixing with other organic substances, with anaerobic fermentation for producing biogas (Xiros et al., 2008; Xiros and Christakopoulos, 2009), but one of the simplest and most self explanatory way could be combustion after drying. Drying however involves further energy consumption and according to Galli and Zilahy (2002) even the well dried substance has relatively poor heating value.

Restructuring the technologies and taking the possibilities repeatedly into consideration may result in solutions which can reduce the energy demand of the given production process by recycling a specific waste/byproduct which was produced during a technology phase. (Korzenszky et al., 2014). We started to investigate the energetic recovery of brewers' spent grains, seeking for possibilities, observing the chemical procedures in the first place.

\section{MATERIAL AND METHODS}

Brewers' spent grains dried under natural circumstances - without energy consumption - $(\mathrm{w}=6-13 \%)$ were at the Szent István University's Department of Chemistry under laboratory conditions in both aerobic and anaerobic ways (Figure 3). Anaerobic circumstances were implemented by leading the gases and fumes through water during the heating in a test tube preventing oxygen to invade. The condensate formed in the experiment was dissolved from the wall of the test tubes and thereafter according to MSZ 21470-2:1981 Hungarian standard by means of microwave reactor (CEM MARS 5 Microwave Accelerated Reaction System) in the presence of $65 \mathrm{~m} / \mathrm{m} \%$ nitric acid and $30 \mathrm{~m} / \mathrm{m} \%$ hydrogen-peroxide disclosed. The element content of resulting solution was analyzed by means of a HORIBA Jobin Yvon ACTIVA-M ICP-OES spectrometer based on the MSZ 1484-3:2006 standard. We were trying to determine with the given examination what level of potentially toxic elementcontent the residual ash, additionally the condensate that was precipitated on the wall of the burning instrument have, following the combustion procedure (energetic utilisation) of brewer's spent grains; furthermore what rate of hazard the emitted fume means to the environment.
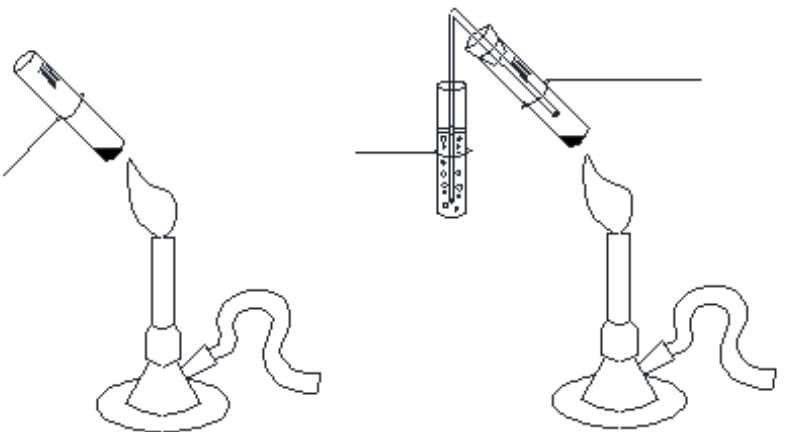

Figure 3 Aerobic and anaerobic combustion

The examination of thermochemical conversion of brewers' spent grains was implemented at the Laboratory of National Agricultural Research and Innovation Centre. In a specifically developed combustion-furnace (Figure 4) the anaerobic high-temperature pyrolysis of the biomass is feasible (Tóvári and Marosvölgyi, 2011; Tóvári et al., 2014).
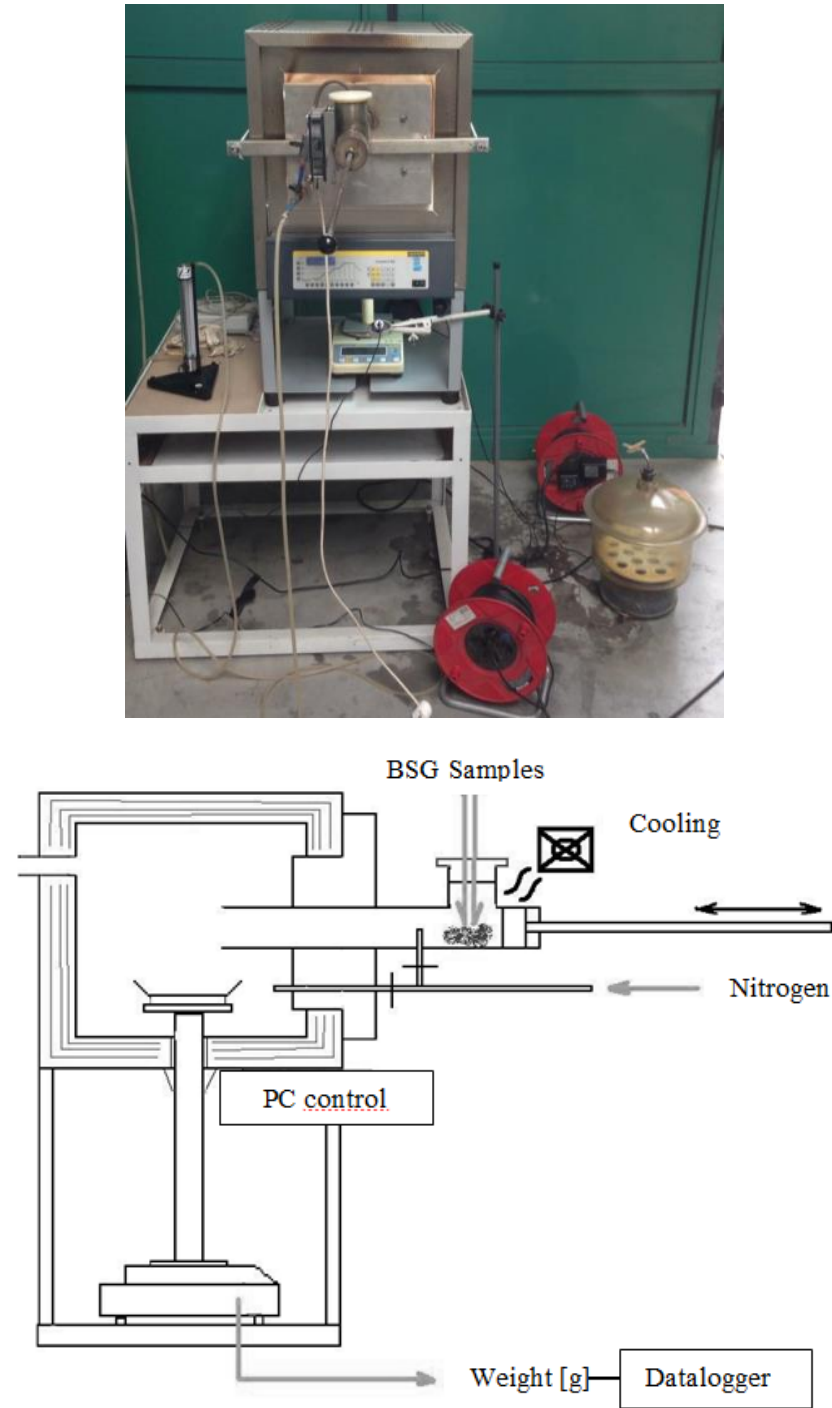

Figure 4 Examination of Biomass’ Pyrolisys (Tóvári et al., 2014)

During thermochemical conversion the weight loss of fuel was constantly recorded. Examinations were implemented at $600^{\circ} \mathrm{C}$. On the biocarbon which 
was formed during the pyrolysis experiment furthermore on the brewer's spent grain - dried by sunshine - which served as the subject of the combustion experiment, a comprehensive energetical examination was executed during which we determined the pyrolysed brewer's spent grain's specific combustion heat value plus thermal value based on MSZ EN 14918:2010 additionally MSZ EN 15296:2011 standards, ash content as per MSZ EN 14775:2010 international standard and the ash melting point based on MSZ EN 15370:2010 technical regulation.

\section{RESULTS AND DISCUSSION}

Thermal values of various fuels were displayed based on references, that of brewer's spent grain samples was depicted using our own measurement results so that the comparison shall be more graphic. Figure 4 shows, that Lower Heating Value (LHV) of dried brewer's spent grain is higher, than that of deposit waste or that of firewood with $12-14 \%$ humidity content. This disproves previous literature results.

Pyrolysis coke produced from brewer's spent grain has a higher heating value (LHV) $\left(\mathrm{H}_{\mathrm{a}}=22,7 \mathrm{MJ} / \mathrm{kg}\right)$ which was formed under anaerobic circumstances at $600^{\circ} \mathrm{C}$ by thermo-convective treatment. One of the greatest advantages of energetical usage realized by means of pyrolysis lies in the fact that substances with lower quality might also be utilized since the environment is not excessively polluted by using this method. From an environmental perspective, emission of solid materials is ignorable with these technologies compared with aerobic combustion techniques.

Figure 6 shows the weight loss percentage of fuels - including BSG - during pyrolysis. Based on the curves BSG's pyrolysis might be compared to herbaceous biomasses. The BSG sample's gasification, in inert atmosphere at $600^{\circ} \mathrm{C}$ temperature, concluded rather rapidly, weight balance occurred after 150 seconds. Rapid reaction is due to the loose texture of the sample, furthermore the resulting larger active surface presence. Results make us draw the conclusion that BSG has to stay for a relatively short period in the reaction chamber during pyrolysis, at this temperature.

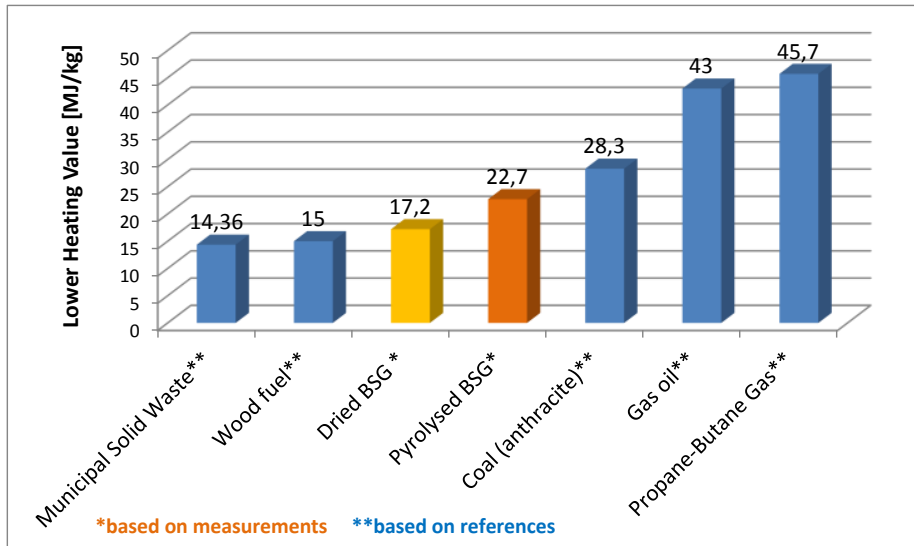

Figure 5 Lower Heating Value (LHV) of different fuel. *based on measurements, **based on references

Brewer's spent grains placed in the test tube were combusted under both aerobic and anaerobic circumstances. It is seen in Table 1 that during combustion under aerobic circumstances the heavy metal content of the condensate sample is reasonably lower, in many cases it is actually below the detection limit of device. Under aerobic circumstances the system shows oxidative conditions, whereas under anaerobic circumstances the reductive conditions dominate. After combustion in oxygen-free environment, the condensate formed on the wall of the test-tube had a higher content of potentially toxic elements, respectively it concentrated in the residual ash. In spite of this during aerobic combustion, because of the fume and scale which are emitted from the system, the potentially toxic element-content of both ash and condensate resulted in lower value, since the scale, fume and the more volatile components (might be oxides as well) could easily quit the system. This is verified by the fact that the ash remained after pyrolysis/combustion had a different weight ratio, $18,24 \mathrm{~m} / \mathrm{m} \%$ under anaerobic furthermore $11,33 \mathrm{~m} / \mathrm{m} \%$ under aerobic circumstances.

Table 1 Heavy metals content of sample and condensate

\begin{tabular}{|c|c|c|c|}
\hline Heavy metals & $\begin{array}{c}\text { BSG sample } \\
{[\mathrm{mg} / \mathrm{kg}]}\end{array}$ & $\begin{array}{c}\text { Anaerobic condensate } \\
{[\mathrm{mg} / \mathrm{kg}]}\end{array}$ & $\begin{array}{c}\text { Aerobic condensate } \\
{[\mathrm{mg} / \mathrm{kg}]}\end{array}$ \\
\hline Al $394.401 \mathrm{~nm}$ & $10,26 \pm 0,84$ & 3,53 & 0,256 \\
\hline Cd $214.441 \mathrm{~nm}$ & BDL & BDL & BDL \\
\hline Cr 205.571 nm & BDL & BDL & BDL \\
\hline Cu 324.754 nm & $6,24 \pm 0,22$ & 1,53 & 0,004 \\
\hline Fe $240.489 \mathrm{~nm}$ & $86,17 \pm 7,45$ & BDL & BDL \\
\hline Mn 257.610 nm & $43,62 \pm 3,25$ & BDL & BDL \\
\hline Ni 222.296 nm & $0,66 \pm 0,1$ & 1,09 & BDL \\
\hline Pb $220.353 \mathrm{~nm}$ & $0,38 \pm 0,32$ & 0,52 & BDL \\
\hline Zn 213.857 nm & $54,33 \pm 1,8$ & 7,54 & BDL \\
\hline
\end{tabular}

Legend: BDL - below the detection limit

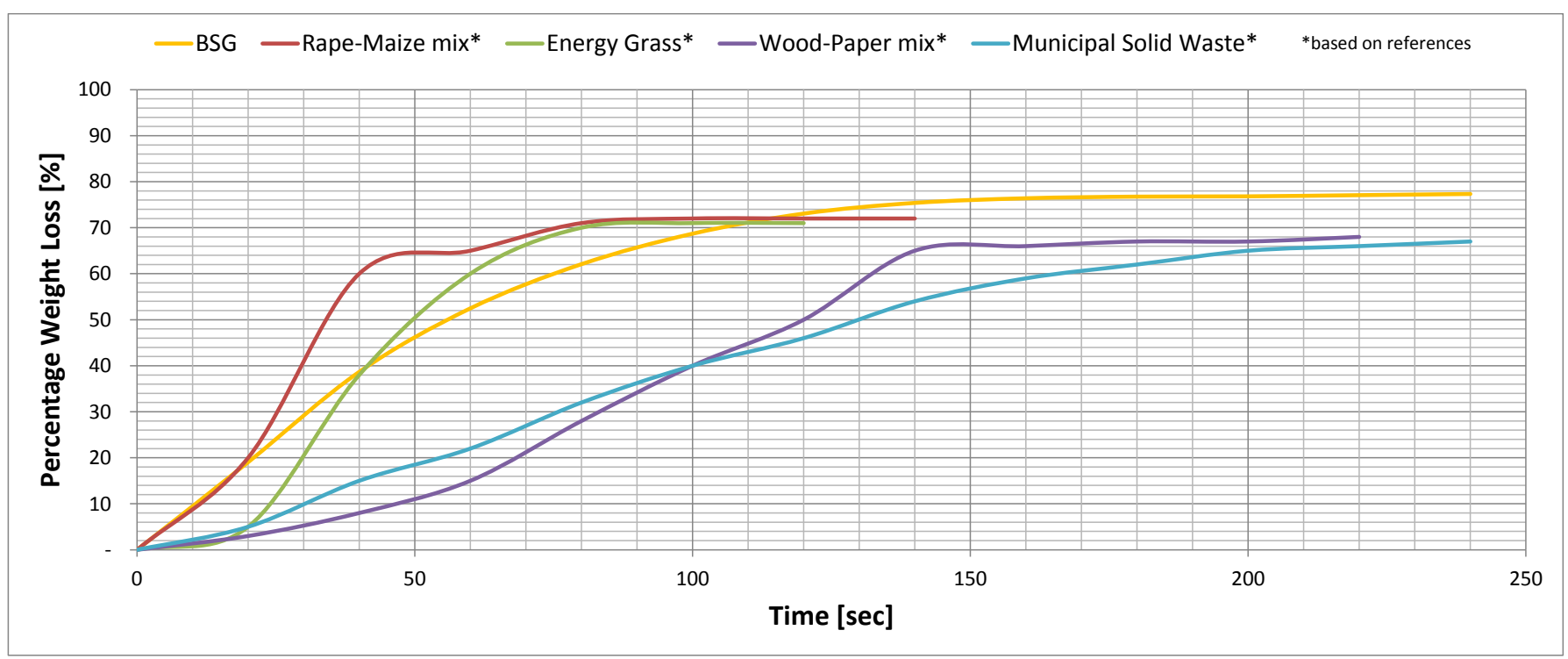

Figure 6 Percentage Weight Loss of fuel as a function of the time in case of pyrolysis 


\section{CONCLUSION}

Energetical examinations of BSG pointed out that they can be utilized with regards to heating value from energetical perspective, but the high humidity content of BSG prevents utilization via direct combustion. Pyrolysis offers a favorable solution but economic issues should be considered here. BSG's local energetical recovery may cover a fraction of the breweries energy consumption and thus reduce the environmental issues originating from its transportation obligations.

We examined the possibilities - by means of chemical procedures - of energetical utilization of BSG which is a technological byproduct of beer brewing, remaining from mashing. Combustion and pyrolysis, however based on the energetical attributes are possibilities, but the breweries' options (i.e. for drying, or obtaining pyrolysis furnace) are restricted. A gas state alternative energy source might offer better options, which might be used by the already installed gas burners. It is worthwhile to examine the biological processes (composting and anaerobic fermentation) just like the chemical procedures and expand our researches into this area as well.

Acknowledgements: We would like to express our appreciation to $\mathrm{HBH}$ brewery in Táborfalva and Legenda brewery in Budapest, since they continuously provided the BSG samples which were crucial for the experiments.

\section{REFERENCES}

ALIYU, S., BALA, M. 2011. Brewer's spent grain: A review of its potentials and applications. African Journal of Biotechnology, 10(3), 324-331.

BAMFORTH, C.W. 2006. Scientific Principles of Malting and Brewing American Society of Brewing Chemists, 246 p. ISBN-13 978-1881696087.

BRIGGS, D.E. 1998. Malts and Malting. Blackie Academic \& Professional, London, 796 p. ISBN-13: 978-0412298004

GALLI, M., ZILAHY, GY. 2002. Possibilities of cleaner production in beer brewing industry. [In: Kerekes, S., Kiss, K. 2002. Hungary at the millennium essay-series], Budapest, 75 p.

GÉCZI, G., HORVÁTH, M., DRÁB, Š., TÓTH, Ž., BENSE, L. 2014. Effect of Malt Milling for Wort Extract Content, Potravinarstvo, 8(1), 33-37. http://dx.doi.org/10.5219/326

IVANIŠOVÁ, E., ONDREJOVIČ, M., DRAPP, Š., TOKÁR, M. 2011. The Evaluation of Antioxidant Activity of Milling Fractions of Selected Cereals Grown int he Year 2010. Potravinarstvo, 5(4), 28-33. http://dx.doi.org/10.5219/163

KORZENSZKY, P., PUSKÁS, J., MOZSGAI, K., LÁNYI, K., MÁK, Z. 2014 Innovation possibilities of a thermolysis plant to be established in Hungary, 20th International Symposium on Analytical \& Applied Pyrolysis: Pyro2014. Birmingham, UnitedKingdom, 2014.05.19-2014.05.23.Paper B143.

MUSSATTO, S.I., DRAGONE, G., ROBERTO, I.C. 2006. Brewers' spent grain: generation, characteristics and potential applications Journal of Cereal Science 43, 1-14. http://dx.doi.org/10.1016/j.jcs.2005.06.001

NARZISS, L. 1981. A sörgyártás. (The Beer Production, in hungarian) Mezögazda kiadó, Budapest, 346 p.

TÓVÁRI, P., OLASZ, ZS., BÁCSKAI, I. 2014. Laboratory modeling of thermo chemical conversion of biomass fuels. Mezögazdasági Technika. LV. 12-14.

TÓVÁRI, P., MAROSVÖLGYI, B. 2011. Laboratory modeling of thermal treatment of biomass fuels. Study, Sopron $11 \mathrm{p}$.

WHITE, J.S., YOHANNAN, B.K., WALKER, G.M. 2008. Bioconversion of brewer's spent grains to bioethanol FEMS Yeast Res 8(7) 1175-1184 http://dx.doi.org/10.1111/j.1567-1364.2008.00390.x

XIROS, C., TOPAKAS, E., KATAPODIS, P., CHRISTAKOPOULOS, P. 2008 Hydrolysis and fermentation of brewer's spent grain by Neurospora crassa. Bioresour Technol 99(13), 5427-5435. http://dx.doi.org/10.1016/j.biortech.2007.11.010

XIROS, C., CHRISTAKOPOULOS, P. 2009. Enhanced ethanol production from brewer's spent grain by a Fusarium oxysporum consolidated system, Biotechnology for Biofuels 2(4), 12 p. http://dx.doi.org/10.1186/1754-6834-2-4 http1:

http://www.cerealsdb.uk.net/cerealgenomics/WheatBP/Documents/DOC_Baking. php 